University of Louisville

ThinkIR: The University of Louisville's Institutional Repository

Electronic Theses and Dissertations

$5-2004$

\title{
The current crisis in orthodontic education : the residents' perspective.
}

Matthew Kawabori Bruner

University of Louisville

Follow this and additional works at: https://ir.library.louisville.edu/etd

\section{Recommended Citation}

Bruner, Matthew Kawabori, "The current crisis in orthodontic education : the residents' perspective." (2004). Electronic Theses and Dissertations. Paper 169.

https://doi.org/10.18297/etd/169

This Master's Thesis is brought to you for free and open access by ThinkIR: The University of Louisville's Institutional Repository. It has been accepted for inclusion in Electronic Theses and Dissertations by an authorized administrator of ThinkIR: The University of Louisville's Institutional Repository. This title appears here courtesy of the author, who has retained all other copyrights. For more information, please contact thinkir@louisville.edu. 


\title{
THE CURRENT CRISIS IN ORTHODONTIC EDUCATION: THE RESIDENTS' PERSPECTIVE
}

\author{
By \\ Matthew Kawabori Bruner \\ B.S., Pacific Lutheran University, 1994 \\ D.D.S., Loma Linda University, School of Dentistry, 1998
}

\author{
A Thesis \\ Submitted to the Faculty of the \\ Graduate School of the University of Louisville \\ In Partial Fulfillment of the Requirements \\ for the Degree of
}

Master of Science

Program in Oral Biology

School of Dentistry

University of Louisville

Louisville, Kentucky

May 2004 


\title{
THE CURRENT CRISIS IN ORTHODONTIC EDUCATION:
}

THE RESIDENT'S PERSPECTIVE

\author{
By \\ Matthew Kawabori Bruner \\ B.S., Pacific Lutheran University, 1994 \\ D.D.S., Loma Linda University, School of Dentistry, 1998
}

A Thesis Approved on

10 February 2004

by the following Thesis Committee:

Anibal M. Silveira, D.D.S.

Thesis Director

Baxter E. Johnson, D.D.S., M.S.

James P. Scheetz, Ph.D.

Janice M. Butters, Ed.D. 


\section{DEDICATION}

I would like to thank God for the opportunity to serve Him in the field of

orthodontics. I dedicate this Masters Thesis to my best friend, my strongest confidant, my continual source of inspiration, and the holder of my heart, my wife, Kathryn. 


\section{ACKNOWLEDGEMENTS}

I am indebted to the following individuals for their assistance with this project:

Dr. Anibal Silveira, Thesis Director and Assistant Program Director of the Department of Orthodontics-Thank you for your encouragement from the very beginning, your energetic help with my thesis preparation, and for your contagious love of orthodontics.

Dr. Ed Johnson, Thesis Committee Member, Program Director and Chairman of the Department of Orthodontics-Thank you for setting the example for all of us; a more supportive, dedicated, and hard working orthodontic chairperson could not be found.

Dr. James Scheetz, Thesis Committee Member and Chief Statistician-Thank you for your approachable, easy going and helpful nature. Without you and your expertise there would be no masters degrees conferred.

Dr. Janice Butters, Thesis Committee Member and faculty of the Department of Periodontics, Endodontics and Dental Hygiene - Thank you for your willingness to step in and share your insight and wisdom and for all the ways your have helped to see this project to fruition. 
Dr. Kelly Hilgers, faculty of the Department of Pediatrics-Thank you for sharing your enthusiasm about research, knowledge of surveys and publication, and for your help throughout this project.

My fellow orthodontic residents - thank you for your input as I developed and tested my survey. I thank you most of all for your invaluable help on 2 August 2003, at the Harvard Lecture Hall, where you distributed and collected my surveys. 


\section{ABSTRACT \\ THE CURRENT CRISIS IN ORTHODONTIC EDUCATION: THE RESIDENTS' PERSPECTIVE \\ Matthew Kawabori Bruner, D.D.S. \\ 10 February 2003}

Purpose. The purpose of this study is to identify orthodontic residents' demographic trends, goals for the future, and perspectives on training.

Method. A 26-item survey, conducted at the Graduate Orthodontic Residency Program, in August 2003, was distributed to residents representing 51 of the 58 orthodontic programs in the U.S. Questionnaires were sent to 5 programs not attending GORP.

Results. Of the 380 questionnaires distributed at the meeting, 295 were returned, while 35 of 50 mailed questionnaires were returned. Total response rate was $77 \%$. Clinical education was the most important factor when choosing a residency. Residents' future plans were to publish their research, earn American Board of Orthodontics (ABO) certification, and work four days a week.

\section{Conclusion.}

Several trends were identified since last surveyed in 1992. Interest in full time academic orthodontic careers continues to decline. The number of females in orthodontic training is increasing. Residents planning to earn $\mathrm{ABO}$ certification increased significantly. 
TABLE OF CONTENTS

PAGE

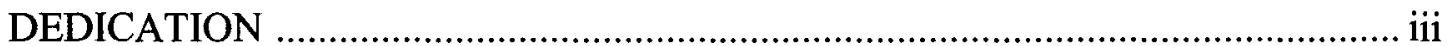

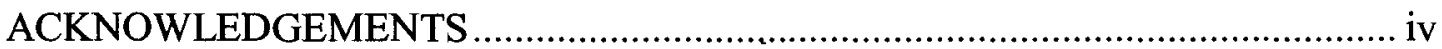

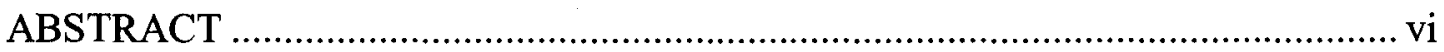

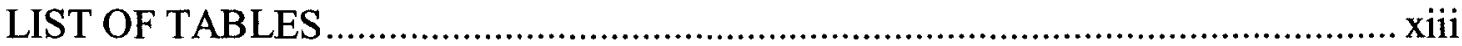

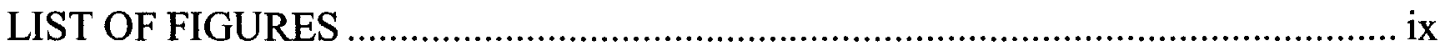

CHAPTER

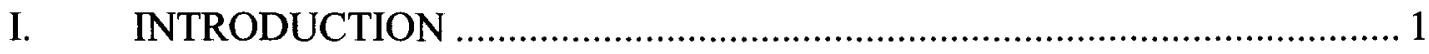

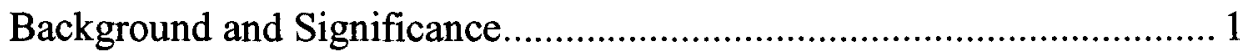

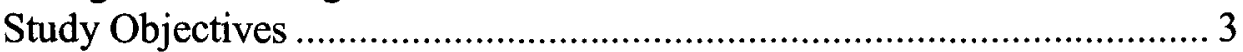

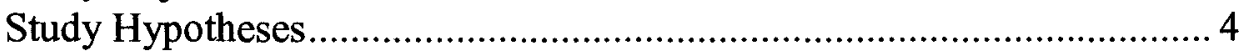

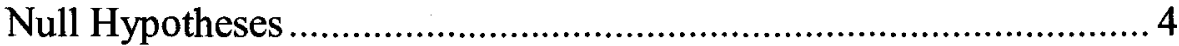

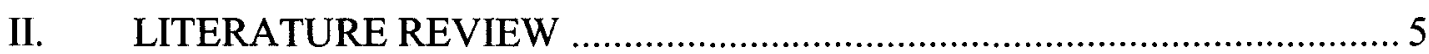

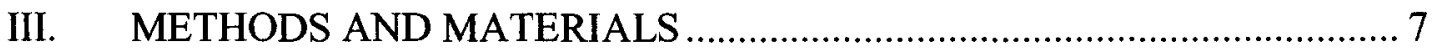

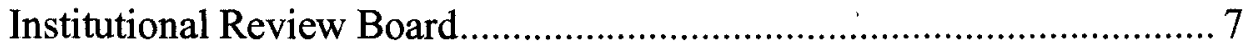

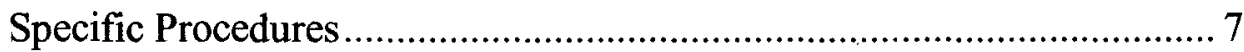

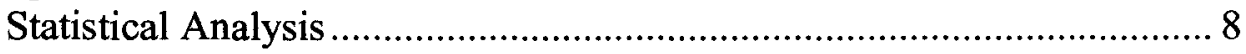

IV. RESULTS

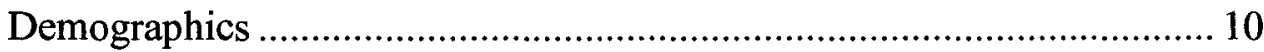

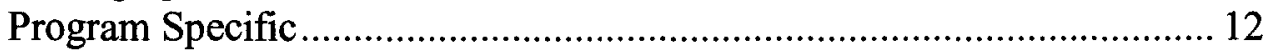

Future Plans and Goals...................................................................... 15

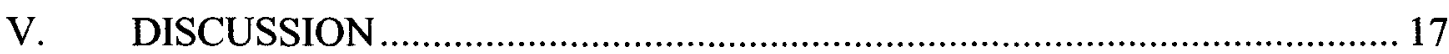

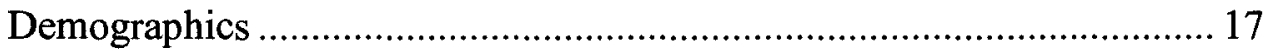

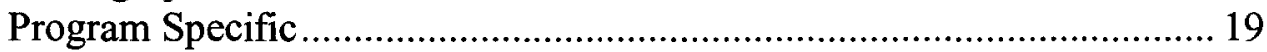

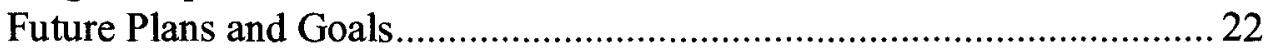

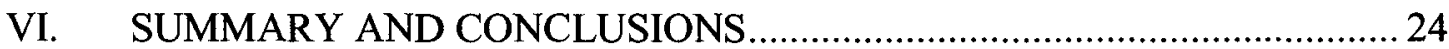

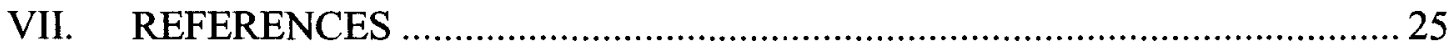

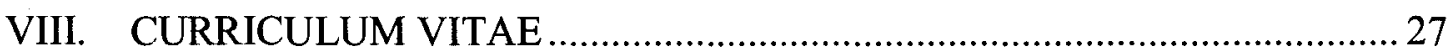




\section{LIST OF TABLES}

TABLE

PAGE

1. Demographic Characteristics of Residents........................................................ 10

2. Activity between dental school and orthodontic training ..................................... 11

3. How satisfied are you with your orthodontic residency program? ........................ 12

4. Most important reason for selecting an orthodontic program............................... 13

5. What additional financial support did you receive while in residency? ................ 14

6. Plans following graduation and anticipated median income …............................ 14

7. In ten years after graduation residents planned to............................. 15 


\section{LIST OF FIGURES}

FIGURE

PAGE

1. Sample of the Questionnaire 9 


\section{CHAPTER I}

\section{INTRODUCTION}

\section{Background and Significance}

The oldest and largest specialty within the field of dentistry today is orthodontics. Orthodontia's roots delve far deeper than the turn of the $20^{\text {th }}$ century, however. In fact, the first texts to describe a system of treatment known as "orthodontics" began to appear around 1850 . One of these early texts, entitled Oral Deformities, ${ }^{1}$ was written by a juggernaut in dentistry named Norman Kingsley. The focus of treatment at this time was on alignment of teeth and facial proportions.

It wasn't until the late 1800 s and the further enhancement of prosthodontics that the idea of occlusion was further developed and began to be understood. Edward H. Angle was credited with much of the development of the concept of occlusion in the natural dentition and his influence was beginning to be felt around $1890 .^{2}$

Angle published articles on malocclusion in the 1890s and with it came the acceptance of what is still taught today in dental schools throughout the world, the "Angle Classification of Malocclusion." Angle's influence grew through the establishment of the first formal orthodontic training programs, "The Angle School of Orthodontics." It was graduates from Angle's school that would go on to become the first chairpersons of orthodontic residency programs in dental schools throughout the country. 
In the 1950s, Charles H. Tweed, one of Angle's former students persuaded the Congress of the State of Arizona to pass the first law recognizing orthodontics as a specialty. This made orthodontics the first dental specialty and Tweed the first official specialist in orthodontics in the country. ${ }^{3}$

As an area of dentistry, orthodontics already had 50 plus years of clinical case studies and reports to fall back on. Historically, and often still practically, orthodontic training has revolved around clinical apprenticeships, externships, and clerkships. However, in order to establish and maintain credibility as a specialty orthodontics had to substantiate itself as a science. The experienced clinician might say that their treatment modality "works well in their hands." However, modern dentistry requires critical thinking that shows why and how a treatment works. More recently there has been a strong push to return to evidenced based orthodontics ${ }^{4}$ and rely much less on the opinion of the clinical expert. This evidenced based medical (dental) model is required if we are to continue to make forward progress and maintain excellence in our specialty.

Just twelve years ago the American Dental Association (ADA) only required orthodontic residency training to be 20 months in duration and the 24 month program was the most common residency length. Currently the accreditation requirement for orthodontic residency training duration is 24 months and the most common residency length is 36 months. Why is the length of training increasing? Many will say that it is increasing because of increased research requirements. Are orthodontic residents interested in research? Are they publishing more articles in peer-reviewed journals? Or do residents simply want to practice clinical orthodontics? Little is known about the perceptions and goals of orthodontic residents in training today. 
What are the kinds of research that are considered to be evidenced based? According to the editor of the American Journal of Orthodontics and Dentofacial Orthopedics (AJODO), David Turpin, in 2002, "The most beneficial studies are reproducible, include control groups, have an adequate sample size, randomize subjects to different treatment modalities, and control for the effects of different variables. The strongest evidence is gleaned from randomized clinical trials. ${ }^{4}$ Is there a double-blind, randomized clinical trial that can calculate and extrapolate the changing trends in orthodontic education?

Of course there is not, but there are surveys. Many have said that surveys are not real science. Surveys are not basic science but they are science and they do provide us with invaluable data that help us to gain understanding. Surveys have several advantages over clinical or experiments studies. ${ }^{5}$ Surveys are efficient tools for measuring simple characteristics of large populations. A well designed survey can access special interest groups that have a high concern for the subject matter being evaluated. Perhaps most significantly and most advantageously, surveys are usually of relatively low cost for the tremendous amount of information obtained.

\section{$\underline{\text { Study Objectives }}$}

The primary objectives of this study were to identify current demographic trends of orthodontic residents, establish and quantify their goals for the future, and to gain insight into their perspectives on orthodontic training. It is also the objective of this study to compare current data with previous studies in order to identify changes over time, establish trends and draw speculative conclusions for the future. This study should help 
orthodontic residents, practicing clinicians and those in the academic establishment better understand orthodontic education from the resident perspective.

\section{Study Hypotheses}

This study expects to find demographic data and data characterizing the opinion and goals of orthodontic residents. Differences between the data in this study and the data from previous studies are expected. It is the goal of this study to establish trends and draw conclusions about the current situation in orthodontic education.

\section{Null Hypotheses}

1. There is no significant difference in demographics amongst orthodontic residents since previously surveyed in 1992.

2. There is no significant difference between the goals of orthodontics residents today and the goals of orthodontic residents surveyed in 1992.

3. There is no significant difference between the perceptions of orthodontics residents today and the perceptions of residents in 1992 with regards to their experience in orthodontic residency training. 


\section{CHAPTER II}

\section{LITERATURE REVIEW}

There have been dozens of published surveys over the last thirty years that pertain to the field of orthodontics. There have been several studies that evaluate things like perceived facial esthetics, practice patterns, or treatment timing. Czarnecki and Nanda ${ }^{6}$ published the results of their survey, "Perceptions of a balanced facial profile," in 1993. They sent out 1300 mailings and had 545 responses, yielding a 42 percent response rate. O'Connor $^{7}$ in 1993, surveyed 1400 active orthodontic specialists and achieved a 58 percent response rate. Yang ${ }^{8}$ et al's 1998 survey of treatment timing sent out 335 questionnaires and returned 137, a 41 percent response rate. These rates may sound low but in actuality are considered to be good. ${ }^{5}$

Gottlieb et al have published well known orthodontic practice surveys in the Journal of Clinical Orthodontics (JCO) for more than twenty years. These surveys are very well known and have provided invaluable data about clinical practice trends in orthodontics throughout the United States. However, they continue to have dismally low response rates. In their most recent study published in three parts between October and December 2003 , Gottlieb et $\mathrm{al}^{9,10,11}$ mailed their survey to 9,282 practices and were only returned 608 usable responses resulting in a valid response rate of $6.6 \%$. 
Despite graduating the highest number of specialists each year, very little has been published regarding residents' opinions on their orthodontic educational experience and their goals upon graduation. Over the past 17 years, four studies by Keim and Sinclair have been conducted that identified trends and evaluated new developments in orthodontic education. ${ }^{12,13,14,15}$ These studies surveyed graduate program directors, gathering valuable data about graduate orthodontic education. In their most recent survey, published in $2002,{ }^{15}$ a 346 item survey was sent to the program directors at 58 schools. Forty four surveys were returned for a response rate of $76 \%$. While the results proved to be very interesting they represent the opinions of the program directors and not of the residents themselves.

There are approximately 722 residents enrolled in orthodontic training programs in the United States. ${ }^{16}$ After a thorough literature review it appears that there has only been one study, conducted in 1992 (published in 1994), that examined orthodontic graduate education solely from the resident perspective. ${ }^{17}$ A follow up survey was indicated to determine changes which may have occurred in the past 11 years. 


\section{CHAPTER III}

\section{METHODS AND MATERIALS}

\section{$\underline{\text { Institutional Review Board }}$}

This study protocol was reviewed and approved by Patricia K. Leitsch, Ph.D., Chairman of the University of Louisville's Human Studies B Committee. In a letter dated July 22, 2003, this study (393-03 Crisis in Orthodontic Education) was approved through the Expedited Review Procedure, according to 45 CFR 46.110(b), category 7. The Subject Informed Consent form was also approved. The study was approved through July 21, 2004.

\section{Specific Procedures}

A 26-item survey was conducted at the Graduate Orthodontic Residency Program (GORP) meeting being held at Harvard University in August 2003. Residents representing 51 of the 58 orthodontic programs in the United States were present. Following the meeting, surveys were sent to 5 of the 7 residency programs which were not in attendance. Of the questionnaires that were mailed, only responses returned within 16 weeks were accepted for analysis.

This survey was comprised of three sections: resident demographics, residency training, and resident goals after graduation. A series of four preliminary surveys were conducted with orthodontic residents at the University of Louisville to assess item clarity 
and ease of instrument completion. The questionnaire was designed to be concise, easy to answer and able to be completed in three minutes. In order to maximize the return rate, the questionnaire was kept to only 1 page, front and back, with questions that were multiple-choice, closed ended, and anonymous. A sample of the survey is shown in Figure 1.

\section{$\underline{\text { Statistical Analyses }}$}

The data collected were entered into Microsoft Excel $2003^{*}$ and analyzed with the Statistical Package for the Social Sciences (SPSS 11.0) ${ }^{* *}$ software. Descriptive statistics were generated to establish means and medians and to make a comparison with results reported in 1992. Data pertaining to residents' future goals were analyzed further with chi square, Mann-Whitney, and odds ratio techniques. Statistical significance was set at $\mathrm{p}<0.05$

Consultation on all data entry and other necessary statistical testing requirements was coordinated through Dr. James P. Scheetz, the chief statistician for this study.

"Microsoft Inc. EXCEL ${ }^{\circledR}$ for Windows 2002; Seattle, WAPSS Inc. SPSS

${ }^{* *}$ SPSS Inc. SPSS ${ }^{\circledR}$ for Windows, Release 11.0 1989-2002; Chicago, IL 
Figure 1. A Survey of Orthodontic Residents

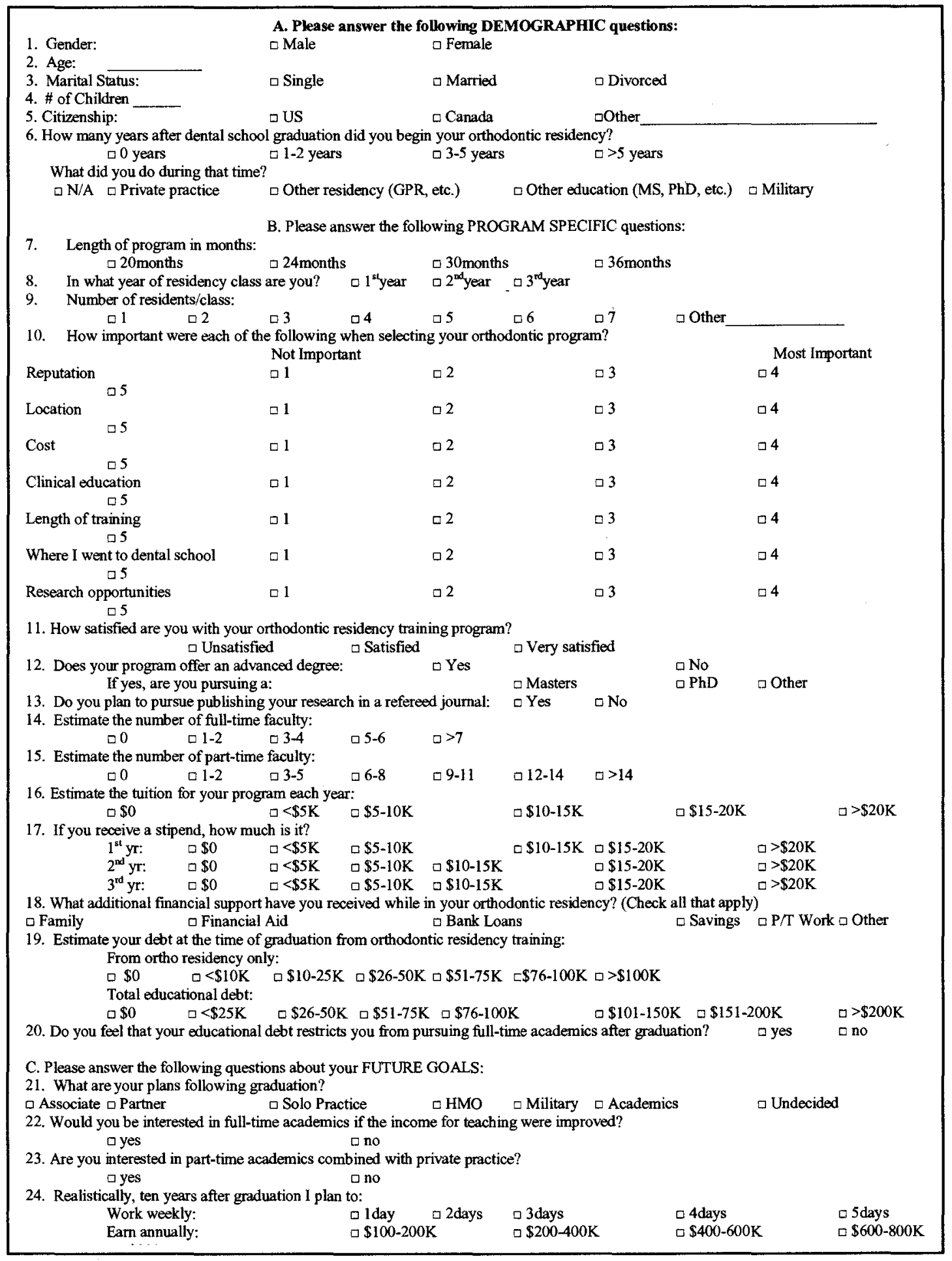




\section{CHAPTER IV}

\section{RESULTS}

Of the 430 total distributed surveys, 330 were completed and returned for a response rate of $77 \%$. The completed surveys represented approximately $46 \%$ of the total population of orthodontic residents in the United States.

\section{DEMOGRAPHICS}

Table I presents demographic characteristics of the survey respondents. Sixty two percent of the respondents were male and $38 \%$ female. The mean age of orthodontic residents was 29 years which varied slightly with gender (males were approximately 9 months older than females). Nearly $60 \%$ of male respondents were married compared to only $48 \%$ of females. More than one-third (36\%) of males had children compared to only $18 \%$ of females. The majority of respondents ( $83 \%$ ) were U.S. citizens, while $9 \%$ were Canadian, and $8 \%$ were from other countries.

Table I. Demographic characteristics of residents

\begin{tabular}{|c|c|c|c|}
\hline & Female 2003 & Male 2003 & Total Valid \\
\hline Number & $38 \%(123)$ & $62 \%(199)$ & 222 (of 330) \\
\hline Mean Age & $28.6 \mathrm{yrs}$ & $29.4 \mathrm{yrs}$ & $29.1 \mathrm{yrs}$ \\
\hline Married & $48.4 \%(61)$ & $59.9 \%(121)$ & $55.5 \%(182)$ \\
\hline Have children & $17.7 \%(22)$ & $36.2 \%(71)$ & $29.9 \%(93)$ \\
\hline Non-US citizens & $20.6 \%(26)$ & $14.5 \%(29)$ & $16.8 \%(55)$ \\
\hline
\end{tabular}


Over half $(56 \%)$ of the residents entered orthodontic training immediately after dental school completion, while $26 \%$ entered one to two years post-graduation, $12 \%$ three to five years, and $7 \%$ more than five years. Seventy percent of the females and $50 \%$ of the males who did not enter directly into orthodontic training immediately after graduation entered within 1-2 years, while $34 \%$ of males entered after $3-5$ years. Forty five percent of males and females completed other residencies (e.g. GPR), $26 \%$ were in private practice, $17 \%$ were in the military, $10 \%$ were completing other formal education (MS, $\mathrm{PhD}$ ), and $1 \%$ were dental school faculty (Table II).

Table II. Activity between dental school and orthodontic training (for those residents not entering orthodontic residency training immediately after dental school)

\begin{tabular}{|c|c|c|}
\hline & $\begin{array}{c}\text { Frequency } \\
(\mathrm{n}=145)\end{array}$ & $\begin{array}{c}\text { Percent } \\
(\%)\end{array}$ \\
\hline General Practice & 38 & 26.2 \\
\hline Other Residency (GPR) & 66 & 45.5 \\
\hline Other Education (MS, PhD) & 14 & 9.7 \\
\hline Military & 25 & 17.2 \\
\hline Other & 2 & 1.4 \\
\hline
\end{tabular}




\section{PROGRAM SPECIFIC QUESTIONS}

The median and mean length of orthodontic residency training in this study was reported as 29 months. Approximately $83 \%$ of residents attended residency programs which offered advanced degrees. Sixty nine percent reported pursuing an advanced degree, of which $88 \%$ were in M.S. programs, $8 \%$ in Ph.D. programs, and 3\% in "other" degree programs. The majority $(71 \%)$ of residents stated that they wanted to publish their research in a refereed journal.

Table III. How satisfied are you with your orthodontic residency program?

\begin{tabular}{|c|c|c|c|c|}
\hline & Very Satisfied & Satisfied & Unsatisfied & Total \\
\hline MS & $104(52.0 \%)$ & $95(47.5 \%)$ & $1(0.5 \%)$ & 200 \\
\hline $\mathrm{PhD}$ & $15(78.9 \%)$ & $3(15.8 \%)$ & $1(5.3 \%)$ & 19 \\
\hline Other & $49(44.5 \%)$ & $58(52.7 \%)$ & $3(2.7 \%)$ & 110 \\
\hline Total & $168(51.1 \%)$ & $156(47.4 \%)$ & $5(1.5 \%)$ & 329 \\
\hline
\end{tabular}

Over half (51\%) of the respondents were "very satisfied" (Table III) with their current training, $47 \%$ "satisfied," and 2\% (5 people) "unsatisfied." There was no significant difference reported between male and female residents with regard to program satisfaction. A much higher percentage of Ph.D. candidates reported being "very satisfied" with their training than did M.S./other degree candidates. 
Residents rated the importance of seven characteristics when choosing their orthodontic residency program as listed in Table IV. Clinical education was most frequently ranked as "most important" and research opportunities as "least important."

Table IV. Most important reason for selecting an orthodontic program

\begin{tabular}{|c|c|c|}
\hline & $\begin{array}{c}\text { Median Response } \\
1=\text { least important } \\
5=\text { most important }\end{array}$ & Ranked as most \\
\hline Clinical Education & 5 & $57.5 \%$ \\
\hline Location & 4 & $33.2 \%$ \\
\hline Reputation & 4 & $30.0 \%$ \\
\hline Length of training & 4 & $26.0 \%$ \\
\hline Cost & 4 & $25.6 \%$ \\
\hline Where I went to dental school & 4 & $6.7 \%$ \\
\hline Research opportunities & 2 & $4.6 \%$ \\
\hline
\end{tabular}

Tuition varied, with $25 \%$ of the residents paying no tuition to $32 \%$ spending over $\$ 20,000$ per year. The median tuition cost reported for all residents was $\$ 10,000-15,000$ per year for each year of residency. Over half of the residents (53\%) utilized financial aid during their orthodontic residencies, $42 \%$ family support, $29 \%$ individual bank loans, $17 \%$ part-time work, and $11 \%$ from other sources (Table V). More females received 
financial support from their families than did males, although this was not statistically significant.

Table $V$. What additional financial support did you receive while in residency?

\begin{tabular}{|c|c|c|c|}
\hline & $\begin{array}{c}\text { Male } \\
(\mathrm{n}=198)\end{array}$ & $\begin{array}{c}\text { Female } \\
(\mathrm{n}=124)\end{array}$ & $\begin{array}{c}\text { Overall } \\
(\mathrm{n}=323)^{*}\end{array}$ \\
\hline Family & $38.4 \%$ & $49.2 \%$ & $42.4 \%$ \\
\hline Financial Aid & $55.6 \%$ & $48.4 \%$ & $52.6 \%$ \\
\hline Bank Loans & $32.3 \%$ & $25.0 \%$ & $29.4 \%$ \\
\hline Savings & $25.8 \%$ & $24.2 \%$ & $25.1 \%$ \\
\hline Part time work & $19.7 \%$ & $12.9 \%$ & $17.0 \%$ \\
\hline Other & $13.1 \%$ & $6.5 \%$ & $10.8 \%$ \\
\hline
\end{tabular}

*This number included the one person in the study that did not specify their gender.

Approximately half of the residents reported that their schools give stipends. In their first year of residency $50 \%$ of the respondents received no stipend while $22 \%$ reported receiving more than $\$ 20,000$. In their second year of residency $45 \%$ of residents reported to be receiving no stipend while $31 \%$ received more than $\$ 20,000$. Third year residents $(n=47)$ reported similar results: $55 \%$ received no stipend while $28 \%$ received more than $\$ 20,000$.

Residents were asked to estimate their debt at the time of graduation from orthodontic residency training. The median debt attributed to orthodontic residency training was reported to be in the range of $\$ 26,000$ - $\$ 50,000$. The median overall educational debt was reported to be in the range of $\$ 101,000-\$ 150,000$. Sixty three percent of residents 
reported feeling that their educational debt restricted them from going into full-time academics.

\section{FUTURE GOALS}

Table VI describes the respondents' plans following graduation and their anticipated median income at ten years after graduating from orthodontic training. Most respondents planned to enter private practice following graduation.

TableVI. Plans following graduation and anticipated median income:

\begin{tabular}{|c|c|c|}
\hline & $\begin{array}{c}\text { Percent } \\
(\mathrm{n}=325)\end{array}$ & Median Income \\
\hline Private Practice & $81.5 \%$ & $\$ 400,000-\$ 600,000^{*}$ \\
\hline HMO & $0 \%$ & N/A \\
\hline Military & $4.6 \%$ & $\$ 200,000-\$ 400,000$ \\
\hline Academics & $3.4 \%$ & $\$ 200,000-\$ 400,000$ \\
\hline Undecided & $6.2 \%$ & $\$ 200,000-\$ 400,000$ \\
\hline Academics and something else & $4.3 \%$ & $\$ 200,000-\$ 400,000^{*}$ \\
\hline Total & $100.0 \%$ & $\$ 200,000-\$ 400,000$ \\
\hline
\end{tabular}

*P $<.05$ for the comparison between the respondents going into "Private practice" and those going into "Academics and something else."

When asked about their interest in full time academics, $40 \%$ reported that they would be interested if the income for teaching were improved. As an adjunct to private practice, $92 \%$ expressed interest in part time academics. 
Table VII describes respondents' ten year goals in terms of (1) the number of days they plan to work per week, (2) the annual income they expect to earn, and (3) whether they plan to pursue certification by the American Board of Orthodontics (ABO). Females expected to earn significantly less annual income than males $(p=.001)$, while working significantly fewer hours per week $(p=.004)$.

Table VII. In ten years after graduation residents planned to:

\begin{tabular}{|c|c|c|}
\hline & Male & Female \\
\hline Days work / week & 4.0 days $^{\mathrm{a}}$ & 3.8 days $^{\mathrm{a}}$ \\
\hline Annual Income (Median) & $\$ 400,000-\$ 600,000^{* *}$ & $\$ 200,000-\$ 400,00^{* *}$ \\
\hline Earn ABO Certification & $87 \%$ & $87 \%$ \\
\hline
\end{tabular}

${ }^{a} p=.004,{ }^{b} p=.001$

The majority of residents (93\%) reported that they would make contributions to the residency in which they trained and $45 \%$ said they would begin making contributions five or more years after graduation. With respect to the amount of their contributions, $64 \%$ reported that $1-3 \%$ of their annual income would be appropriate while $25 \%$ thought that $4-6 \%$ of their annual income was reasonable. Only $3 \%$ said that they would not give any money back to the program in which they trained. 


\section{CHAPTER V}

\section{DISCUSSION}

Several changes in orthodontic resident demographics, perception of training, and individual goals were found since last surveyed in $1992 .{ }^{17}$ Many of these changes may impact the future of orthodontics. 380 questionnaires were distributed to the residents attending lecture at the GORP meeting. Another 50 questionnaires were mailed to five residency programs that did not attend the meeting. After 16 weeks, 35 questionnaires were returned and added to the 330 from the meeting, providing a response rate of $77 \%$. Ten more surveys were returned after 20 weeks and were not included in the statistical

analyses. The exceptional response rate of this survey ${ }^{18}$ indicates that orthodontic residents are interested in this topic. While the 1992 survey had 168 responses out of the 218 residents surveyed at GORP, the overall sample surveyed only represented $29 \%$ of residents in the nation at that time. In the current study the sample of 330 residents represents $46 \%$ of the residents in the United States.

\section{DEMOGRAPHICS.}

Although the number of females in orthodontic training is increasing, the number of males continues to exceed the number of females. The percentage of residents surveyed that were female increased from $25 \%$ as reported in $1992^{17}$ to $38 \%$ in the current study. A survey of program directors in $2002^{15}$ reported an even higher percentage $(50 \%)$ of 
female orthodontic residents in the U.S. The variation in results may be due to sample selection, since the current study primarily sampled residents attending the GORP 2003 meeting where fewer females may have chosen to attend.

Several studies have concluded that female dentists are less likely to own their own practice, are more likely to work fewer days per week, and are more likely to work fewer hours per day than males. ${ }^{19,20,21}$ With this in mind, the reported increase in the percentage of female orthodontic residents may require an increase in the number of orthodontists in the U.S. in order to meet patient needs.

\section{Family Status}

Married females increased from $42 \%$ in 1992 to $48 \%$ in 2003, while married males declined from $64 \%$ in 1992 to $60 \%$ in 2003 . The overall percentage of residents who have children increased. Females with children doubled from $9 \%$ in 1992 to $18 \%$ in 2003, while males with children increased slightly from $33 \%$ in 1992 to $36 \%$ in 2003 . The percentage of non-U.S. citizens in orthodontic residency training who were female increased from $5 \%$ in 1992 to $21 \%$ in 2003 , but remained relatively constant for males (approximately $15 \%$ ). The mean age of orthodontic residents (29 years) remained unchanged since last surveyed in $1992 .{ }^{17}$

\section{Experience After Dental School}

The percentage of residents entering orthodontic training immediately after dental school increased slightly from $50 \%$ in 1992 to $55 \%$ in 2003 . Of those residents who did not enter immediately after graduation, the majority $(46 \%)$ received other residency 
training (e.g. GPR). This greatly increased from the $27 \%$ reported in 1992 which may indicate that competition for acceptance into orthodontic residency training has increased. Dentists with general practice experience, however, decreased from $35 \%$ in 1992 to $26 \%$ in 2003 . This could be due to higher debt loads carried by new graduates, ${ }^{22}$ as the cost of orthodontic education continues to increase. ${ }^{15}$ Additionally, after generating income in a general dental practice and taking on more responsibilities (such as a family), a young dentist may have difficulty returning to residency training. The percentage that entered orthodontic residency training from the military $(17 \%)$, from other graduate studies (10\%), and from teaching (1\%) remained unchanged since the 1992 survey. $^{17}$

The median number of years between dental school and beginning orthodontic training was 1-2 years. A higher percentage of females entered orthodontic training within 1-2 years after graduating from dental school, while a higher percentage of males entered orthodontic training after 3 or more years. For females with young families or for females desiring to start a family, returning to residency while balancing personal and professional responsibilities may be difficult.

\section{PROGRAM SPECIFIC QUESTIONS}

In 2001, the mean length of orthodontic residency training was 29 months. ${ }^{16}$ In the current study, the mean and median length of training was reported as 30 months with $39 \%$ of the programs being two year ( 24 month) programs. In the current study, a few respondents stated that they were in programs exceeding 36 months. Two were in 4 year (48 month) master's degree programs, and one was in a 5 year (60 month) Ph.D.

program. There has been a continual reduction in the number of 24 month programs 
however, since 1983, and an increasing number of $30-36$ month programs. ${ }^{15}$ Therefore, it appears that the average length of orthodontic residency training is increasing.

More orthodontic residencies are offering advanced degrees, increasing from $77 \%$ in $1992{ }^{17}$ to $82 \%$ in 2003 . Of the residents pursuing an advanced degree, those pursuing a Ph.D. increased slightly from 5\% in 1992 to $8 \%$ in 2003 .

Most orthodontic residents were "satisfied" or "very satisfied" with their residency training. Interestingly most residents pursuing their Ph.D.'s were "very satisfied" (79\%) with their programs. Only five residents from the whole survey were unsatisfied (2\%); four were in their final year of residency. Due to the small number of unsatisfied residents, no conclusions could be drawn to explain their dissatisfaction.

As orthodontic programs are moving to 36 months (from 24 months), most programs are increasing their residents' clinical case load and decreasing the amount of time available for research. ${ }^{15}$ Interestingly, this correlates with what the residents reported as the "most important" reason for choosing their orthodontic program, "clinical education." The criteria "least important" to residents were "research opportunities" and "where they went to dental school." This is also correlated to what residents reported regarding their future goals: $82 \%$ of respondents planned to enter private practice and only $3 \%$ planned to pursue full time academics. With such a low interest in academics, it was surprising that $71 \%$ of residents planned to publish their research in a refereed journal.

Tuition has increased in most areas of education including orthodontics. ${ }^{15}$ In 2001, the average tuition for first year orthodontic residents was reported as $\$ 15,179$ and $\$ 9,289$ for the second year residents. ${ }^{16}$ Although previous studies report that orthodontic 
residency tuition varies by year, the median tuition cost in the current study was $\$ 10,000$ to $\$ 15,000$ for each year with fluctuations only between individual programs.

There was large variation in those receiving stipends. Generally speaking, half of the respondents reported receiving stipends and of that group almost $50 \%$ reported receiving $\$ 20,000$ or more per year. This data tells us that there are a large number of residents that rely on money from stipends.

Recently, stipends for non-hospital based dental residencies have been eliminated from Graduate Medical Education (GME) funding. Stipends awarded for orthodontic education may become a thing of the past. Where do residents find the additional financial support required to get through residency? Fifty three percent of respondents utilized financial aid with only slight differences by gender. More females received family support, while more males worked part time or received bank loans. Ten percent of the residents reported "other" sources of financial support, many of whom were military residents (either active duty or scholarship).

No studies, with the exception of Lindauer et al in $2003,{ }^{22}$ have addressed the issue of debt amongst orthodontic residents. Lindauer reported that the average $2^{\text {nd }}$ year orthodontic residents' educational debt was $\$ 132,120$. This is consistent with the median reported overall educational debt of $\$ 101,000-\$ 150,000$ in the current study. While these numbers are very high it should be noted that the debt attributed to the cost of orthodontic education alone was approximately $1 / 3$ to $1 / 4$ of the overall educational debt reported by residents. The majority of residents $(63 \%)$ reported feeling that educational debt restricts them from pursuing full-time academics. Therefore, it can be concluded that large debt loads may impact residents' future plans. 


\section{FUTURE GOALS}

When asked about their plans upon graduation, very few of the respondents (3\%) showed an interest in full-time academics. This has actually decreased from the 5\% reported by Lindauer et al, in 2003 , who also stated that low income potential in academics is the primary reason orthodontists enter into private practice. ${ }^{22}$ The problem of enticing more orthodontists to go into teaching as a career is not new, and it is not unique to our profession. ${ }^{23}$ Many have been taking note that there is a serious crisis in orthodontic education today. The overwhelming majority of orthodontic residents (92\%) report being interested in part time academics in conjunction with private practice. So few are interested in full time academic orthodontics that $35 \%$ of orthodontic graduate programs in the United States report having at least 1 vacant faculty position. ${ }^{22}$ What can these programs do to attract new orthodontists when only $3 \%$ of residents are reporting an interest in full time academics? Interestingly, $40 \%$ of respondents in the current study reported that they would consider pursuing academic careers if the income were improved. The academic community should take note and increase salaries for orthodontic faculty.

Evaluating their ten-year goals, most residents planned to work four days a week, with median income goals for females $(\$ 200,000-\$ 400,000)$, being significantly less than males $(\$ 400,000-\$ 600,000, p=.011)$. Female respondents did report planning to work significantly fewer hours per week, but this difference was only by 2 hours ( 3.76 days compared to 3.96 days, $p=.004$ ), hardly justifying the $\$ 200,000$ discrepancy in anticipated income. 
With the satisfaction expressed by nearly all ( $98 \%)$ orthodontic residents with their training it makes sense that $93 \%$ of the residents report a willingness to contribute to the programs in which they trained. Most residents plan to contribute between one and six percent of their annual income.

One of the most significant findings was the tremendous increase in residents who plan to pursue $\mathrm{ABO}$ certification. In $1992^{17}$, only $2 \%$ of residents ( $0 \%$ of females and $3 \%$ of males) planned to earn $\mathrm{ABO}$ certification, which increased to $87 \%$ for both male and female residents in 2003 . This $85 \%$ increase may be attributed to the strong effort to make certification more user friendly by the American Association of Orthodontists (AAO), the American Association of Orthodontics Foundation (AAOF), and the $\mathrm{ABO}$ in order to encourage orthodontists to pursue their certification. 


\section{CHAPTER VI}

\section{SUMMARY AND CONCLUSIONS}

A number of conclusions can be drawn from this study. First, the number of residents who plan to achieve $\mathrm{ABO}$ certification has significantly increased since last surveyed in1992. Second, interest in full time academic careers in orthodontics continues to decrease. However, $40 \%$ of orthodontic residents reported that they would consider full time academics if the salaries were increased. Third, the majority of residents (63\%) reported feeling that educational debt restricts them from pursuing full-time academics. Therefore, it can be concluded that large debt loads may impact residents' future plans. Finally, female orthodontic residents have significantly lower income expectations than males, while they plan to work nearly the same number of hours per week.

Several future studies are warranted. First, as the percentage of orthodontists who are female increases, future studies need to address potential differences in practice patterns between male and female practitioners. Second, with the reported decrease in graduating residents planning to pursue academic careers, future studies should evaluate the impending crisis in orthodontic education. Third, as more orthodontic training programs become 36 month programs, studies need to examine the justification of the additional year of schooling. Finally, a follow up to the current study is warranted in 10 years to determine if the responding residents achieved $\mathrm{ABO}$ certification. 


\section{REFERENCES}

1. Kingsley NW: Treatise on oral deformities as a branch of mechanical surgery, New York, 1880, Appleton.

2. Proffit WR. Contemporary Orthodontics, $3^{\text {rd }}$ Edition, St. Louis, 2000, Moseby.

3. Vaden J, Merrifield L. Charles Henry Tweed (1895-1970). Am J Orthod Dentofac Orthop 1999;115(3):333-334.

4. Turpin DL. Evidence-based orthodontics. Am J Orthod Dentofacial Orthop 2000;118:591.

5. Backstrom CH. Survey Research. New York: John Wiley and Sons, 1981.

6. Czarnecki ST, NandaRS. Perceptions of a balanced facial profile. Am J Orthod Dentofac Orthop 1993;104:180-7.

7. OConnor. Special Article. Am J Orthod Dentofac Orthop 1993;Feb(163-170).

8. Yang EY, Kiyak HA. Orthodontic treatment timing: a survey of orthodontists. Am J Orthod Dentofac Orthop 1998;113:96-103.

9. Keim RG, Gottlieb EL, Nelson AH, Vogels DS $3^{\text {rd }} .2003$ JCO Orthodontic Practice Study. Part 1. Trends. J Clin Orthod 2003 Oct;37(10):545-53.

10. Keim RG, Gottlieb EL, Nelson AH, Vogels DS $3^{\text {rd }} .2003$ JCO Orthodontic Practice Study. Part 2: Practice success. J Clin Orthod. 2003 Nov;37(11):607-15.

11. Keim RG, Gottlieb EL, Nelson AH, Vogels DS 3rd. 2003 JCO Orthodontic Practice Study. Part 3: Practice growth and staff data. J Clin Orthod. 2003 Dec;37(12):667-75.

12. Sinclair PM, Alexander RG. Orthodontic graduate education survey. Am J Orthod Dentofac Orthop 1984;85:175-81.

13. Sinclair PM, Rudolf DJ. Orthodontic graduate education survey-1983-1989. Am J Orthod Dentofac Orthop 1991;100:465-71.

14. Rudolph DJ, Sinclair PM. Orthodontic graduate education survey 1983-1994. Am J Orthod Dentofacial Orthop 1997 Oct;112(4):418-24. 
15. Keim RG, Sinclair PM. Orthodontic graduate education survey, 1983-2000. Am J Orthod Dentofac Orthop 2002; 121:2-8

16. 2001/2002 Survey of Advanced Dental Education, ADA.

17. Keith O, Proffit WR. Orthodontic training: the residents' perspective. Am J Orthod Dentofac Orthop 1994;106:649-53.

18. Fowler FJ. Survey Research Methods, 2nd edition. Sage: Newbury Park, 1993.

19. Morris J, Harrison R, Caswell M, Lunn $\mathrm{H}$. The working patterns and retirement plans of general dental practitioners in a Midland Health Authority. Prim Dent Care 2002 Oct; 9(4):153-6

20. Dolan TA. Gender trends in dental practice patterns. A review of current U.S. literature. J Am Coll Dent 1991 Fall; 58(3):12-8.

21. Waldman HB. Changing number and distribution of orthodontists: 1987-1995. Am J Orthod Dentofac Orthop 1998; 114:50-4

22. Lindauer SJ, Peck SL, Tufekci E, Coffey T, Best AM. The crisis in orthodontic education: Goals and perceptions. Am J Orthod Dentofac Orthop 2003; 124:480-7.

23. Turpin DL. AAO coordinates specialties to recruit and retain dental faculty. Am J Orthod Dentofac Orthop 2002; 121:1. 


\title{
CURRICULUM VITAE
}

\author{
Matthew Kawabori Bruner \\ 4825 Oak Pointe Drive \\ Louisville, $\mathrm{KY} 40245$ \\ (502) 417-3522
}

matthew.bruner@aaomembers.org

\section{EDUCATION:}

1. Post-doctorate: Orthodontics, University of Louisville School of Dentistry, Louisville, KY, 2002-2004

2. Flight Dental Surgeon School 9/00 - 11/00.

3. General Dentistry Practice, DENTAC Hawaii 1998-2001.

4. Officers Basic Course 004-98, San Antonio TX. 7/98 - 9/98.

5. Doctorate: Loma Linda University School of Dentistry, Loma Linda, CA 1994-1998. DDS 5/98

6. Undergraduate: Pacific Lutheran University, Tacoma, WA 1990-1994. BS $5 / 94$

7. High School: Interlake High School, Bellevue, WA 1986-1990.

\section{PROFESSIONAL CERTIFICATES:}

1. Western Regional and Hawaii Board Certification.

2. State of Washington License in Dentistry.

3. State of Hawaii License in Dentistry

4. State of Kentucky License in Dentistry

5. Branemark Implant Restoration Certificate.

6. Advanced Cardiac Life Support.

7. Basic Life Support.

8. DEA Certificate and Number.

\section{PROFESSIONAL ORGANIZATIONS:}

1. American Association of Orthodontists.

2. American Dental Association.

\section{PROFESSIONAL HONORS AND AWARDS:}

1. First Army Flight Dental Surgeon, Graduate AFSPC NOV 2000.

2. American College of Dentistry Award, LLUSD 1998.

3. Senior Advanced Status, LLU 1997-1998.

4. Student Leadership 1994-1997. 
5. Distinguished Military Graduate, Pacific Lutheran University (PLU)

6. Army ROTC Advanced Designee Scholarship, PLU 1990.

7. PLU Baseball Talent Award Scholarship, 1990.

8. PLU Music Scholarship, 1990

\section{WORK EXPERIENCE:}

1. Orthodontic Resident-08/2002 to Present

2. General Dental Officer, in charge of $25^{\text {th }}$ I.D.(L) Aviation Brigade, Schofield Barracks, Hawaii-10/2000 to $1 / 2001$

3. General Dentist-Clinic Leader responsible for another dentist, three assistants, one hygienist/DTA, four chairs, and 2,100 active patients-4/ 99 to 7/2000

4. General Dentist-Team Member, responsible for three chairs, and shared 2,000 active patients with one other doctor $-9 / 98$ to $4 / 99$.

\section{MILITARY AWARDS:}

1. Army Commendation Medal.

2. Army Achievement Medal, with one oak leaf cluster.

3. U.S. Army Air Assault Badge

4. U.S. Army Airborne Badge

5. U.S. Army Flight Dental Surgeon

\section{RESEARCH:}

1. "Aerobiological Contamination of Air Ventilation Systems in the LLU Implantology Operatories." Loma Linda University, 1998 